\title{
真空紫外光プロセスの現状と将来
}

\author{
佐々木亘 \\ 宮崎大学工学部電気電子工学科 E 889-2192 宮崎県宮崎市学園木花台西 1-1
}

（1999 年 2 月 10 日受理）

\section{A Review of the Present Status and Future Prospects on Materials Processing Using Vacuum-Ultraviolet Light}

\author{
Wataru SASAKI \\ Department of Electrical and Electronics Engineering, Faculty of Engineering, University of Miyazaki \\ 1-1 Nishi, Gakuen-kibanadai, Miyazaki 889-2192
}

(Received February 10, 1999)

\begin{abstract}
Efficient and intense light sources in the vacuum-ultraviolet spectral region and their applications have been reviewed. High-intensity dielectric-barrier-discharge $\mathrm{Ar}, \mathrm{Kr}$ and $\mathrm{Xe}$ excimer lamps were emphasized. Rare gas excimer lasers such as $\mathrm{Ar}_{2}, \mathrm{Kr}_{2}$ with electron beam excitations and discharge pumped $\mathrm{F}_{2}$ lasers were briefly mentioned as coherent VUV light sources. Potentialities of ArKr hetero-eximer lasers were also discussed. Applications of VUV light to surface cleanings, $\mathrm{SiO}_{2}$ thin films decompositions and compositions on $\mathrm{Si}$ wafers were reviewed.
\end{abstract}

\section{1. はじめに}

紫外域の KrFレーザー（波長 $249 \mathrm{~nm}$ ）が 64 MDRAM の量産ラインのステッパー光源として実用化され，次の

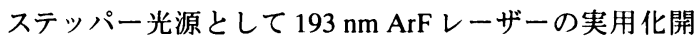
発が精力的に行われている。一方, 波長 $100 \mathrm{~nm}$ から 200 $\mathrm{nm}$ の真空紫外光の光子エネルギーはほとんどの物質の 原子間結合力より大きいため, 真空紫外光の照射によっ て物質を構成する原子の電子遷移励起を起こし, 前期解 離過程を経て原子の結合を切断することができる。この 現象を利用したプロセスは，従来の光プロセスのように 照射された光が熱エネルギーとして吸収され，熱解離， 溶融，蒸発などの過程による物質プロセスとはまったく 異なる。すなわち，1 光子で 1 つの原子結合を切断する， 純粋に光子のみによる作用で，「光量子プロセス」と呼 ばれている。

このような真空紫外光子による新しい光量子プロセス が可能なことは数年前から実証されていたが')，実用化 に耐えるような光源がなかったためにあまり注目されな かった。しかし，放電励起による $F_{2} レ$ レ゙ーの普及と

E-mail: sasakiw@opt.miyazaki-u.ac.jp
1991 年に Kogelschatz ら ${ }^{2)}$ にる希ガスエキシマランプ の開発により, 種々の応用研究がなされ, 実用化の可能 性がみえてきた。

現在，工業的に実用化の可能性がある真空紫外光源と しては, インコヒーレントな光源として，希ガスエキシ マランプ，コヒーレントな光源として，希ガスエキシマ レーザーおよび $\mathrm{F}_{2} レ$ レ゙ーである。したがって，本論 文では上記の 3 種類の真空紫外光源に絞って解説する。

\section{2. インコヒーレント光源}

真空紫外光による種々のプロセスの実用化が注目され るきっかけを与えたのは, Kogelschatzらによる希ガス および希ガス八ライドェキシマランプの報告である2。 彼らは, オゾナイザーなどに用いられていた, 誘電体バ リアー放電（無声放電ともいわれる）により，希ガスエ キシマや希ガスハライドエキシマが効率よく生成される ことを報告した。これらのエキシマは紫外域から真空紫 外域の波長でレーザー発振が 1970 年代のはじめに報告 され(3), レーザーとして盛んに研究された。レーザー媒 質としての研究結果から, 理論的には真空紫外域のスペ クトルを非常に高い効率で発光することが明らかになっ ていだ)。しかし，希ガスエキシマのレーザー発振にお 
いては数気圧以上で $60 \mathrm{MW} / \mathrm{cm}^{3}$ 程度の強い励起をしな ければならないため, 放電励起による発振が困難であっ た。高気圧での放電はすぐにアーク放電に移行するため, エキシマの生成が困難である。

一方, 筆者らは希ガスエキシマレーザーを放電励起で 発振させようと種々の試みを行う中で, ジェット放電励 起5, 6) と無声放電励起?) で希ガスエキシマおよび $\mathrm{ArKr}$,

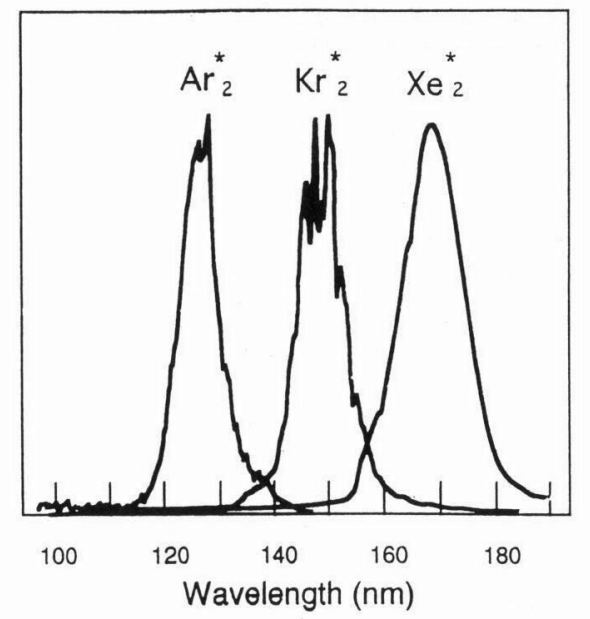

Fig. 1 VUV spectra of rare gas excimer lamps.

Table 1 Characteristics of silent discharge excimer lamps.

\begin{tabular}{lcccr}
\hline & $\lambda(\mathrm{nm})$ & $\Delta \lambda(\mathrm{nm})$ & $P(\mathrm{~W})$ & $\eta(\%)$ \\
\hline $\mathrm{Ar}_{2}{ }^{*}$ & 126 & 9 & 0.9 & 3.4 \\
$\mathrm{Kr}_{2}{ }^{*}$ & 147 & 12 & 3.4 & 13.1 \\
$\mathrm{Xe}_{2}{ }^{*}$ & 172 & 13 & 5.3 & 20.4 \\
$\mathrm{Ar}_{2}{ }^{*} / \mathrm{Kr}_{2}{ }^{*}$ & 145 & 30 & 0.54 & 2.2 \\
$\mathrm{Kr}_{2}{ }^{*} / \mathrm{Xe}_{2}{ }^{*}$ & 162 & 30 & 3.4 & 13.6 \\
\hline
\end{tabular}

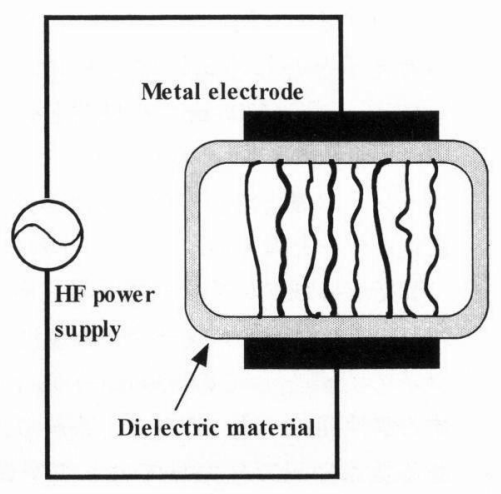

(a)
$\mathrm{KrXe}$ 等の希ガスヘテロエキシマが効率よく生成される ことを明らかにした。Fig. 1 に無声放電希ガスエキシマ ランプの発光スペクトルを, Table 1 に発光特性を示す。 発光スペクトルはピークの值で規格化してある。このほ かには近赤外付近に弱い発光が見られるだけである。イ ンコヒーレントなエキシマ光の発光効率は入力電気エネ ルギーに対して, $\mathrm{Ar}$ エキシマで $1 \%, \mathrm{Xe}$ エキシマで 20 $\%$, で従来の真空紫外光源に比べ非常に高効率である。 その他のへテロエキシマもこれらの間の值である。

また, 五十風らはこれらの無声放電のエキシマ光源を 実用光源として精力的に開発し ${ }^{8)}$, 希ガスエキシマラン プおよび希ガスハライドエキシマランプとして製品化に 成功し, 真空紫外光の実用化に大きく貢献した。

無声放電は Fig. 2（a）に示すように金属電極を誘電 体で覆っているので, 高気圧放電においてもアークに移 行することがなく, マイクロ放電と呼ばれる直径数十 $\mathrm{nm}$ の微少な放電が多数生成しては数 $\mu \mathrm{s}$ で消滅する持続 放電形態である。このマイクロ放電は平均電子温度が数 $\mathrm{eV}$ あ, 通常のグロー放電 ( $1 \mathrm{eV}$ 以下) より高く, 希 ガスエキシマを効率よく生成することができる。

放電電極が誘電体で覆われているので，放電回路の等 価回路は Fig. 2 (b) に示すように誘電体の静電容量 $C_{\text {diele }}$ と放電空間の静電容量 $C_{\mathrm{dsc}}$ の直列回路となる。したがっ て, 直流放電は困難で, $10 \mathrm{kV}$ 程度で数十 $\mathrm{kHz}$ の高周波 電源を使用する。周波数は前述の直列回路の共振周波数 に近い值が用いられる。真に放電空間だけにかかる電界 を測定することが不可能なため, 放電特性を表す換算電 界 $E / p$ を求めるには, 電極間電圧から計算すると $E / p=$ $20 \mathrm{~V} / \mathrm{mmHg}$ 程度が適当である。

放電管への入力電力は放電管の形状, 電極間隔, ガス

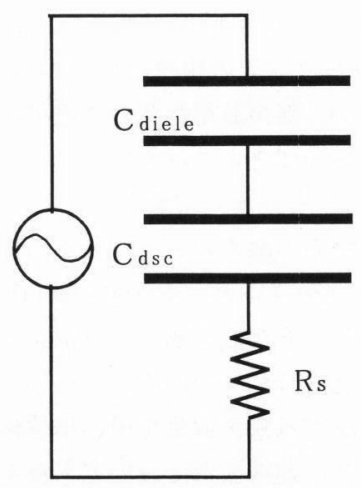

(b)

Fig. 2 Schematics of a dielectric-barrier-discharge (silent discharge) lamp (a) and its equivalent circuit (b). 


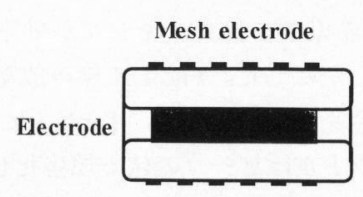

(A)

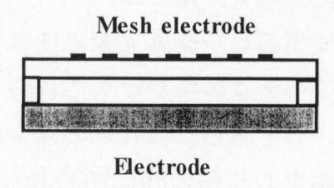

(C)

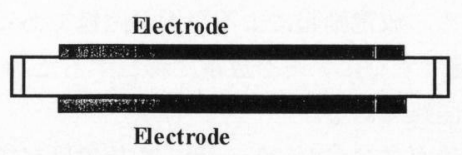

(B)

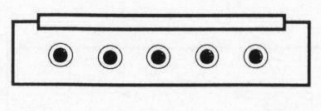

Electrodes

(D)

Fig. 3 Various types of rare gas excimer lamps.

圧, ガスの種類により大きく変化するが, $1 \mathrm{~cm}^{3}$ 当たり $0.5 \mathrm{~W}$ 程度の電力を入れることができる。電極間隔, 放 電管の形状を適当に設計することにより，最大出力が得 られるガス圧を 1 気圧付近にすることが可能である。

無声放電希ガスエキシマランプは, 上述のように非常 に高性能の真空紫外光源であるが，1つ欠点を有してい る。それは, 後に述べるように真空紫外光子はほとんど の原子結合を切断するため, 発生した真空紫外光によっ て電極に用いた誘電体が分解する。特に, 誘電体として 石英を用いた場合は，Si と O 結合が切断され希ガス 中に $\mathrm{O}_{2}$ ガスが発生する。 $\mathrm{O}_{2}$ ガスは $200 \mathrm{~nm}$ 以下の波長 に対して, 吸収係数の非常に大きな広い吸収バンド（シ ユーマン・ルンゲバンド) を有しているため, 発生した エキシマ光を吸収して急速にランプの出力が低下する。 後述のように, Si と O の結合の切断には $9 \mathrm{eV}$ 以上の光 子エネルギーが必要とされる。したがって, この問題は Ar エキシマランプだけに生ずるはずであるが, $\mathrm{Kr}$ エキ シマ, Xeエキシマでも同様な現象が見られる。その理 由は, $9 \mathrm{eV}$ 以下の波長では光の照射だけでは Si-O 結合 の切断は起こらないが, 無声放電電極の誘電体の場合は プラズマ中で真空紫外光にさらされるので, 相乗効果に より $9 \mathrm{eV}$ 以下の光子でも結合の切断が生じるものと思 われる。石英ガラスからの酸素の放出による出力低下を さけるため，筆者らは誘電体として $\mathrm{MgF}_{2}$ や $\mathrm{LiF}$ を用い ることを提案している。また五十風らは放電館内にゲッ ターを設けて長寿命化をはかっている。

希ガスエキシマランプは無声放電を用い単位体積当た りの放電入力が小さく, 連続放電においても放電管自体 の温度上昇は大きくない。したがって, 放電管の形状が 自由に設計でき, 現在知られているだけでも，Fig. 3 に 示すよ5に 2 重円筒型, 直線型, 平面型, 内部電極型な どがある。良質の合成石英ガラスは Xe エキシマランプ
の $172 \mathrm{~nm}$ の光を $80 \%$ 以上透過するが, $\mathrm{Kr}$ エキシマの $147 \mathrm{~nm}$ および $\mathrm{Ar}$ エキシマ $126 \mathrm{~nm}$ 光の透過空材は, $\mathrm{MgF}_{2}$ 又は $\mathrm{LiF}$ しかない。したがって, $\mathrm{Ar}$ エキシマラン プおよび Kr エキシマランプは材料面の制約から製作で きるランプの形状に制限を受ける。筆者らは Fig. 3 に示 す, 内部電極型 (D) の構造と $\mathrm{MgF}_{2}$ 空を用いて, 大面 積照射ランプを開発した。しかし, 現在, 我が国で入手 できる $\mathrm{MgF}_{2}$ 空は最大で直径 $150 \mathrm{~mm}$ で, 今後材料の開 発が必要とされる。

\section{3. コヒーレント光源}

現在までに発振が報告されている真空紫外域のレーザ 一としては, 希ガスハライドの ArFレーザー（波長 193 $\mathrm{nm}), \mathrm{F}_{2}$ レーザー $(157 \mathrm{~nm})$ および Arエキシマ(126 $\mathrm{nm}), \mathrm{Kr}$ エキシマ $(147 \mathrm{~nm})$, および Xeエキシマ(172 $\mathrm{nm})$ の 3 種類の希ガスエキシマレーザーがある。これ らのなかで, ArFレーザーの波長は真空紫外域に属する が, 放電形式, 使用光学素子, 開発の歷史的過程などか

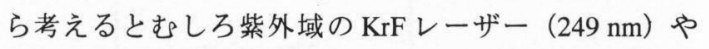
$\mathrm{XeCl}$ レーザー $(308 \mathrm{~nm})$ の仲間として扱われている。す でに次世代のリソグラフィ用ステッパー光源として量産 ラインへの導入にむけ精力的に開発が進められ, 完成し たレーザーと考えられるので, 本解説では取り上げない。

真空紫外域のレーザーで, 現在最もその開発が希求さ れているのは, ArFレーザーの後にくる半導体リソグラ フィの光源としての $130 \mathrm{~nm}$ から $150 \mathrm{~nm}$ の波長で発振 する高性能レーザーである。高繰り返し動作が可能性で ある放電励起で発振している真空紫外レーザーは, $F_{2}$ レーザーのみである。希ガスエキシマレーザーのうち $147 \mathrm{~nm}$ の $\mathrm{Kr}$ エシマレーザーおよび波長 $135 \mathrm{~nm}$ の $\mathrm{ArKr}$ ヘテロエキシマレーザーはリソグラフィ光源とし ては最適な波長域であるが，Krエキシマレーザーは電 
子ビーム励起でのみ発振が確認されており, $\mathrm{ArKr}$ ヘテ ロエキシマに至ってはまだ発振の報告がなされていな い。

$\mathrm{F}_{2}$ レーザーは放電励起で発振する真空紫外域のレー ザーとして, 実用化への開発が進められているが，レー ザーガスとして化学的活性の非常に強い $F_{2}$ ガスを使用 するため多くの技術的困難を克服しなければならない。 $\mathrm{F}_{2}$ レーザーは希ガスハライドレーザーよりさらに強励 起の放電条件を必要とするうえ, 光学素子の光吸収およ び光損傷が大きい真空紫外域ではレーザー装置の構成上 多くの制限を受ける。この点においては後述の希ガスエ キシマレーザーに一歩を譲る。しかし, 放電励起で発振 が達成されている唯一の真空紫外レーザーとして, 技術 的進歩が期待されている。

希ガスエキシマレーザーは, 真空紫外域の広い範囲に わたって発振波長を有しており, レーザーガスとしても

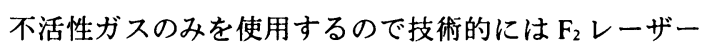
より多くの利点を有している。しかし, 現在までのとこ ろ電子ビーム励起による発振しか実現されておらず, 装 置が大型であることと低繰り返し動作のため実用化に対 して大きな問題点を抱えている。

筆者等をはじめ多くの研究者が, 希ガスエキシマレー ザーの放電励起発振を試みたが, 現在のところ何れも成 功していない ${ }^{9 \sim 12)}$ 。希ガスエキシマレーザーは下準位が 解離的ポテンシャル曲線を有しているので, 理論的には 下準位のポピュレーションがない 4 準位レーザーであ り, 容易に反転分布が形成されるように思われるが，実 際には非常な強励起が必要である。その理由は, 真空紫 外域においては光学素子の性能が, 可視域や紫外域に比 較して劣るためスレッシュホールドを越すには大きな利 得を必要とする。例えば, $\mathrm{Kr}$ エキシマの $147 \mathrm{~nm}$ に対し て最近やっと誘電体多層膜の共振器鏡が入手できるよう になり, 反射率 95\%-70\%程度の共振器が構成できる ようになったが, Arエキシマの $126 \mathrm{~nm}$ ではアルミの蒸 着膜の上に $\mathrm{MgF}_{2}$ を蒸着して酸化を防いだ反射鏡で 70$80 \%$ の反射率が得られるのみであり，しかもこれを製 作してくれるところは筆者の知るかぎり 1 社（米国）し かない。部分透過鏡にいたっては, $\mathrm{MgF}_{2}$ 基板をそのま ま使用するしかない情況である。具体的には, $10^{15}$ から $10^{16} \mathrm{~cm}^{-3}$ 程度の上準位密度を実現する必要がある。し たがって, 希ガスハライドエキシマレーザーの数倍もの 強励起を必要とする。このため数気圧以上のガス圧で安 定な放電を行う必要があるので, 短パルス放電以外の放 電形態は技術的に非常に困難である。筆者らのこれまで の知見によると $50 \mathrm{MWcm}^{-3}$ 程度の励起強度が必要であ る。更に, レーザー上準位が寿命の短い（約 $5 \mathrm{ns）1}$ 重
項と寿命の長い（Ar エキシマで $\mu \mathrm{s}, \mathrm{Xe}$ エキシマでns） 3 重項に分かれており，3 重項からのミキシングによる 1 重項への供給を使わないと前述のような高密度の反転 分布を実現することは難しい。

更に, 我々が長年行ってきた電子ビーム励起実験の結 果によると, 希ガスエキシマレーザーの上準位はレーザ 一発振光を吸収してイオン化される。この吸収係数はか なり大きく誘導放出断面積に比べて無視できない。した がって, レーザー発振は, 上準位の生成速度, 誘導放出 による光の増幅およびレーザー光による上準位の破壊の $3 つ の$ 機構が微妙なバランスになったとき発振が維持さ れると考えられる。この発振の難しさが放電励起による 発振条件を非常に厳しいものにしている。

以上の情況から真空紫外域のレーザーは実用的な光源 としては十分な開発が達成されておらず, 今後の開発に よる光源としての完成度がどこまで進歩するかが, 実用 化への鍵を握っている。

\section{4. 真空紫外光の応用}

真空紫外光プロセスには, 実用化技術の開発段階にあ るものから, まだ研究室レベルでその可能性を確かめて いる段階のものまで, 非常に広範囲にわたっている。実 用化に近いものについては, 本特集の中でそれぞれの専 門の方々が詳しい報告をされているのでそちらに譲り, 本稿ではその他のものについてのべる。

真空紫外光の応用を考えるときその特徴として光の波 動性に注目し, 集光性を利用して超微細加工を指向する ものと, 粒子性に注目して光子エネルギーによる光量子 プロセスを利用する応用がある。

波動性を利用した応用としては, 半導体プロセスのス テッパー光源として ArFレーザーが用いられようとし ている。波長 $193 \mathrm{~nm}$ で $0.18 \mu \mathrm{m}$ の刻線による 256 DRAM のプロセスが計画されている。その次の世代としては 1 GDRAM 更には 4 GDRAM のステッパー光源として真空 紫外の $150 \mathrm{~nm}$ 近傍の光源の開発が希求されている。そ の候補としては, $\mathrm{F}_{2} レ$ レ゙ーの $157 \mathrm{~nm}, \mathrm{Kr}$ エキシマレ ーザーの $147 \mathrm{~nm}$ および $\mathrm{ArKr}$ ヘテロエキシマレーザー の $135 \mathrm{~nm}$ 等が候補となる。この中では, 波長的には $\mathrm{ArKr}$ ヘテロエキシレーザーの $135 \mathrm{~nm}$ が最も望ましいが, 上

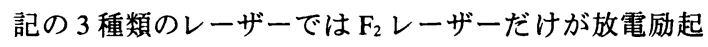
による放電が得られており, 他の 2 つは電子ビーム励起 のみで放電励起による発振が達成されていない。生産ラ インへの導入のためには, 放電励起による高繰り返し動 作が必須条件となる。

波動性の利用ではないが, 真空紫外レーザーの今ひと つの态用としては, レーザーアブレーションがある。真 
空紫外レーザーによるアブレーションは，長波長レーザ 一のアブレーションと異なり, 加工面が滑らかになる等, 特徵的なことが報告されているが, 詳細は後述の論文を 参照されたい。

真空紫外域のレーザーの工業的な応用としては, $\mathrm{ArF}$ レーザーのステッパー光源として開発が進められている だけであるが，将来さらに高集積 IC のステッパー光源 としての応用が大きく進展するものと期待されている。

次に，真空紫外光子による光量子プロセスとしては， 光エッチング, 光 CVD, 有機材料の表面改質, 表面洗 浄, $\mathrm{SiO}_{2}$ 膜の除去, 光分解, アッシャ一等, 真空紫外 光子による原子間結合の切断を効果的に利用した応用が すでに研究室レベルでは原理実証がされている。これら の内, 光エッチング, 光 CVDによる膜生成, 表面改質, については本特集に詳しい報告があるのでそちらに譲 り，その他のものについて解説する。

希ガスエキシマランプを用いた表面洗浄は, 1994 年 頃から液晶ディスプレイ用ガラスの洗浄, リソグラフィ 用マスクやシリコンウエハーの洗浄に適用する研究が開 始された。特に Xeエキシマランプを用いた液晶ディス プレイ用ガラスの洗浄は五十風らにより詳しく研究開発 され，すでに生産ラインに導入されるまでに至ってい る ${ }^{13)}$ 。現在真空紫外光の実用化としては, 最も進んでい る分野であろう。

$\mathrm{SiO}_{2}$ のバンドギャップは約 $9 \mathrm{eV}$ で, $\mathrm{Ar}$ エキシマの 9.8 $\mathrm{eV}$ の光子を照射すると価電子帯から伝導帯へ電子が励 起され, Si と O の結合が切断されることが $\mathrm{Ar}$ エキシマ レーザーを用いて明らかにされている(4)。筆者らはこの 現象を利用して Ar エキシマランプの照射により Si ウエ ハーの自然酸化膜を除去する実験を行った。光照射のみ による Si とOの結合の切断は酸化膜の性質に大きく依 存することがわかった。

真空紫外光子による原子結合の切断を利用すると，多 くの大気污染物質の分解に利用できることは理論的には 明らかである。例えば, $\mathrm{NO}_{\mathrm{x}}, \mathrm{CO}_{2}, \mathrm{O}_{3}$, フロン, ダイ オキシン等, 現在大きな社会問題になっている活染物質 ほとんどに適用可能であろう。しかし, 実証例としては, 筆者の知る限りでは, H. Esrom ら ${ }^{15)}$ の $\mathrm{NO}_{\mathbf{x}}$ の分解例が あるだけである。フロンやダイオキシンの分解は今後大 いに期待されるテーマである。

\section{5. 将 来 展 望}

本解説で述べたように，真空紫外光と物質の相互作用 は従来の可視光より波長の長い光と物質の相互作用とは 大きく異なる。紫外域のレーザーが利用できるようにな ったときにこのような光量子現象が期待されたが，やは
り熱作用の方が支配的であった。すなわち，真空紫外域 になり，明確に光量子が利用できるようになった。しか し，この光が手軽に使えるようになってまだ日が浅いた め, これから種々の応用が考えられ開発されるものと思 われる。現段階で, 正確な予測をすることはもちろん不 可能である。

光源においては，希ガスエキシマレーザーの放電励起 による発振が実現すれば，大きく様相を変えるものと思 われる。エキシマランプについては, 更に高出力, 高効 率化が追求されることも必要とは思われるが，むしろ応 用範囲の拡大の方が重要である。広い範囲への実用化開 発が望まれる。

态用面では，まったく新しい応用も多く開発されると 思われるが，現在考えられているだけでも，光洗浄，半 導体プロセス, 光分解, 生物工学への応用など大きく発 展するものと思われる。

\section{文献}

1）黒澤 宏, 佐々木 亘, 瀧川靖雄 : レーザー研究 20 , 11 (1992).

2) B. Gellert and U. Kogelschatz: Appl. Phys. B 52, 14 (1991).

3) C.K. Rhodes (ed.): “Excimer Lasers”, 2nd ed. (Springer, Berlin, Heidelberg, 1984).

4) D.C. Lorents: Physica C 82, 19 (1976).

5) J. Kawanaka, S. Kubodera, W. Sasaki, K. Kurosawa, K. Mitsuhashi and T. Igarashi: IEEE J. Selected Topics in Quantum Electron. 1, 852 (1995).

6) J. Kawanaka, S. Kubodera, W. Sasaki and K. Kurosawa: Appl. Phys. B 65, 609 (1997).

7) S. Kubodera, M. Honda, M. Kitahara, J. Kawanaka, W. Sasaki and K. Kurosawa: Jpn. J. Appl. Phys. 34, L 618 (1995).

8) H. Sugahara, T. Igarashi, H. Matsuno, Y. Ohnishi, T. Hiramoto and Y. Asahina: Ext. Abs. of 41st Spring Meeting of Jpn. Soc. of Appl. Phys. 30 p-ZE-3 (1994).

9) T. Efthimiopoulos, B.P. Stoicheff and R.I. Thompson: Opt. Lett. 14, 624 (1989).

10) J.E. Tucker, M.F. Masters, B.L. Wexler and S.K. Searles: Opt. Lett. 17, 288 (1992).

11) H. Phillips, S. Kubodera, R. Sauerbrey, F.K. Tittel and P. J. Wisoff: IEEE J. Quantum Electron. 27, 95 (1991).

12) W. Sasaki, K. Kurosawa and S. Matsuzono: Technical Digest of CLEO '92 12, 112 (1992).

13) S. Iso, H. Matsuno, T. Igarashi, H. Sugahara and T. Hiramoto: Ext. Abs. 56th Autumn Meeting of Jpn. Soc. of Appl. Phys. 28-ZT-7 (1995).

14) K. Kurosawa, W. Sasaki, Y. Takigawa, M. Ohmukai, M. Katto and M. Okuda: Appl. Surf. Sci. 70/71, 712 (1995).

15) H. Esrom and U. Kogelschatz: Thin Solid Films 218, 231 (1992). 